\title{
Effect of Bio-Fertilizer on physiology of growth and development of maize ( Zea mays L.) in Sulaimani region
}

Aram A. Mohammed

College of Agriculture- Univ. of Sulaimani

\begin{abstract}
Effect of inoculation with Phosphorus biofertilizer and different dozes of nitrogen and $\mathrm{P}_{2} \mathrm{O}_{5}$ on the physiology of growth and development of maize were studied through conducting two different field-experiments at two different locations, Bakrajo ( $35^{\circ} 34^{\prime \prime} 307^{\prime} \mathrm{N}, 765 \mathrm{masl}$ ) and Kanipanka location ( $35^{\circ} 22^{\prime \prime}$ $37^{\prime} \mathrm{N}, 545 \mathrm{masl}$ ), in sulaimani region. The treatments included, $\mathrm{T}_{1}$ (no biofertilizer, only recommended NP), $\mathrm{T}_{2}(50 \%$ recommended NP+ Phosphorus biofertilizer), $\mathrm{T}_{3}$ ( Recommended $\mathrm{N}+$ phosphorus biofertilizer), In addition to vegetative traits (such as plant height, LAI, No. of days to 50\% silking, No. of days from $50 \%$ silking to physiological maturity $(\mathrm{PM})$ ), and reproductive traits (such as 500kernel weight, Biological Yield (BY), Yield, and Harvest Index(HI)), the root-shoot ratio(R/S) was studied in three different stages of growth pre-silking, at- silking and post-silking, results showed increasing in dry weight of root-shoot ratio and significant differences among studied traits, showing positive response of maize hybrid to phosphorus biofertilizer.
\end{abstract}

\section{INTRODUCTION}

Biofertilizer is a material containing microorganism(s) added to a soil to directly or indirectly make certain essential elements available to plants for their nutrition. Various sources of biofertilizers include nitrogen fixers, phytostimulators, phosphate solubilizing bacteria, plant growth promoting rhizobacteria, etc... (Shekh, 2006). Application of biofertilizers became of great necessity to get a yield of high quality and to avoid the environmental pollution (Shevananda, 2008). One of more important factors that impact the physiology of plants growth and development is the availability of nutrients which can uptake by plants from soil. Phosphate and nitrogen are important for plant growth, however plants have a limited ability to extract them from the environment, and thus need microbes involved in "nutrient recycling," to help a plant uptake and absorb these nutrients at optimal concentration, while plants donate waste byproducts to microbes for food. With this symbiotic relationship, plants develop stronger and bigger root systems. The larger the plants' roots, the more living space and food there is for the microbes to use. In a way, microorganisms serve as biofertilizers (El-kholy ., 2005). An example is the fungus Penicillium bilaii, which allows plants to absorb phosphates from the soil. It

does this by producing anorganic acid which dissolves soil phosphates into a form which plants may use. A biofertilizer made from this organism is applied either by 
coating seeds with the fungus (called inoculation), or applying the fertilizer directly

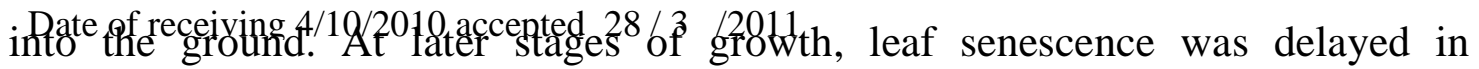
inoculated plants, thus favoring dry matter accumulation and grain filling (Sarig et al ., 1990). In field experiments in Argentina, corn inoculated with Azospirillum lipoferum showed double the seeds per ear, an increase in seed dry weight by 59 $\%$, and a significant stimulation in root development at harvest time (Fulchieri and Frioni, 1994). Another example is the bacterium Rhizobium. (Shekh, 2006). Use of these microorganisms as environment friendly biofertilizer helps to reduce the much expensive phosphatic fertilizers. Phosphorus biofertilizers could help to increase the availability of accumulated phosphate (by solubilization), efficiency of biological nitrogen fixation and increase the availability of $\mathrm{Fe}, \mathrm{Zn}$ etc., through production of plant growth promoting substances (Kucey ., 1989). Trials with PSB indicated yield increases in rice (Tiwari ., 1989), maize (Afzal ., 2005) and other cereals (Ozturk et al ., 2003). Increased root, shoot weight with dual inoculation in maize have been reported by (Chabot et al ., 1993), while grain yields of the different maize genotypes treated with Azospirillum spp. Varied between 1700 and $7300 \mathrm{~kg} \mathrm{ha}^{-1}$ ( Salmone and Dobereiner, 2004). Root elongation assay was used for selection of effective plant growth promoting rhizobacteria, and data revealed that rhizobacterial isolates significantly differed in their potential to promot the elongation (Shaharoona and Zahir, 2006). Use of biofertilizers offers agronomic and environmental benefits for intensive agricultural systems in Egypt, and data obtained revealed that using Azospirillum brasilense or commercial biofertilizer cerealin with half $\mathrm{N}$ rate $(144 \mathrm{kgN} / \mathrm{ha})$ caused a significant increase in yield (Mohammed et al ., 2001). Seed inoculation with Rhizobium, phosphorus solubilizing bacteria, and organic amendment increased seed production of the crop(Panwar et al ., 2006). Increasing yield was attributed to the plant growth promoting substances by root colonizing bacteria more than the biological nitrogen fixation, ( Lin et al ., 1983) stated that yield increased due to promoting root growth which in turn enhancing nutrients and water uptake from the soil. There were positive and synergistic interactions between factors like interactions between mycorrhizal inoculation and phosphate biofertilizer on $\mathrm{N}$ concentration and phosphate biofertilizer and vermicompost on $\mathrm{P}$ concentration (Darzi et al ., 2009).

\section{MATERIALS AND METHODS}

Two different field- experiments were conducted in two different locations in sulaimani region namely Bakrajo and Kanipanka during the summer season of 2009 on a silty clay soil, by using Complete Randomized block Design with three replications. Seeding dates were in July 14 and 16 at both locations, respectively. Experimental unit area was $7.5 \mathrm{~m}^{2}(3 \mathrm{~m} \times 2.5 \mathrm{~m})$, consisted 4 rows, the planting 
patterns of the (MSI4317 Hybrid, which handed from Agricultural Research Center of Sulaimani) consisted of $70 \mathrm{~cm}$ between rows and $20 \mathrm{~cm}$ between plants, The traits includes bio and chemical fertilizer application, $\mathrm{T}_{1}$ (no biofertilizer, only recommended chemical fertilizer of Nitrogen and Phosphorus, $200 \mathrm{~kg} \mathrm{~N} \mathrm{ha}^{-1}$ and $200 \mathrm{Kg}$ ha- ${ }^{1}$ T.S.P $48 \% \mathrm{P}_{2} \mathrm{O}_{5}$ ), $\mathrm{T}_{2}$ (Bio-Fertilizer $100 \mathrm{~g} \mathrm{ha}^{-1}+50 \%$ of recommended fertilizer NP), and $\mathrm{T}_{3}($ Recommended Nitrogen fertilizer + Bio-Fertilizer $100 \mathrm{~g}$ ha $\left.{ }^{1}\right)$.

Commercial phosphorus biofertilizer( tested at the libraries of Agricultural research Center of Sulaimni) are commonly used with vegetable crops, for increasing production and improvement of quality, was used throughout this investigation, as recommended by the producer( $100 \mathrm{~g}$ of biofertilizer inoculated with seeds will sown to one hectar area). In order to obtaining the root-shoot ratio, the weight of roots and shoots was measured at three different stages of growth which were pre-silking ( one month after emergence), at silking stage, and postsilking (one month after silking). Immediately after sampling, the fresh weight of samples was recorded before being dried at $80^{\circ} \mathrm{C}$ in an aerated oven to constant dry weight. Vegetative and reproductive growth characters were measured such as, leaf area which was measured by using al-Sahoky method [Al-sahoky, 1990 ], Plant height, No. of days required to $50 \%$ silking, No.of days required from $50 \%$ silking to physiological maturity(PM), and weight of $500 \operatorname{kernel}(\mathrm{g})$, biological yield(Mg ha-1), yield(Mg ha-1), and Harvest Index(HI). Meterological data of the two locations used especially during the period post silking for determining the longivity of leaves and their abilities to photosynthesis.

\section{RESULTS AND DISCUSSION}

Table 1. indicates that there were significant differences in the response of maize hybrid to the effect of treatments on its vegetative growth traits that studied in the two locations, in Bakrajo the superiority was to $\mathrm{T}_{3}$ which represents the effect of phosphate biofertilizer and full dose of recommended Nitrogen, exceeding $\mathrm{T}_{1}$ ( recommended NP) in plant height, LAI, and No.of days from $50 \%$ silking to physiological maturity(PM), and followed by $\mathrm{T}_{2}$ (Biofertilizer and $50 \%$ of recommended NP) which exceeded $\mathrm{T}_{1}$ in No. of days from seeding to $50 \%$ silking,

Table (1): Studied vegetative traits in Location 1 and Location 2.

\begin{tabular}{|c|c|c|c|c|c|c|c|c|}
\hline \multirow[b]{2}{*}{$\begin{array}{c}\text { Treatme } \\
\text { nts }\end{array}$} & \multicolumn{4}{|c|}{ Location 1. bakrajo } & \multicolumn{4}{|c|}{ Location 2. Kanipanka } \\
\hline & $\begin{array}{c}\text { Plant } \\
\text { Height } \\
\mathrm{cm}\end{array}$ & LAI & $\begin{array}{c}\text { No. of } \\
\text { days } \\
\text { to } \\
50 \% \\
\text { silking }\end{array}$ & $\begin{array}{l}\begin{array}{l}\text { No.of } \\
\text { days } \\
\text { from } \\
50 \% \\
\text { silking } \\
\text { to PM }\end{array} \\
\text { S }\end{array}$ & $\begin{array}{c}\text { Plant } \\
\text { Height } \\
\mathrm{cm}\end{array}$ & LAI & $\begin{array}{l}\text { No. of } \\
\text { days } \\
\text { to } \\
50 \% \\
\text { silking }\end{array}$ & $\begin{array}{c}\text { No.of } \\
\text { days } \\
\text { from } \\
50 \% \\
\text { silkin } \\
\text { g to }\end{array}$ \\
\hline
\end{tabular}




\begin{tabular}{|c|c|c|c|c|c|c|c|c|}
\hline & & & & & & & & PM \\
\hline $\mathrm{T} 1$ & 108.333 & 5.548 & 63.666 & 58.833 & 131.833 & 5.95 & 53 & 54 \\
\hline $\mathrm{T} 2$ & 111.666 & 5.166 & 65.666 & 60.166 & 135.5 & 6.166 & 54 & 51 \\
\hline $\mathrm{T} 3$ & 114 & 6.574 & 64.666 & 62 & 137.833 & 6.823 & 52.666 & 56.5 \\
\hline L.S.D & 2.926 & 0.608 & 1.308 & 2.069 & 3.943 & 0.627 & 0.755 & 1.683 \\
\hline
\end{tabular}

While in Kanipanka $\mathrm{T}_{3}$ exceeded $\mathrm{T}_{1}$ in plant height and LAI, and No.of days from $50 \%$ silking to physiological maturity, but $\mathrm{T}_{2}$ exceeded $\mathrm{T}_{1}$ and $\mathrm{T}_{3}$ in the No. of days to $50 \%$ silking.

According to the data of table 1, the effect of biofertilizer was evaluated positively, there were an increase in plant height, LAI, and increase in the seed filling period which determined by the number of days required from $50 \%$ silking to PM. at both locations, and the maize response was more greater in kanipanka location than Bakrajo due to favorability of environmental factors of that location in comparison to the first location, the positive results of using phosphate biofertilizer may related to increasing the availability of nutrients as a biological activity of it; Results were similar to previous research(Shekh, 2006, El-kholy et al ., 2005 and Sarig et al ., 1990).

Table 2 show significant differences among reproductive traits in both locations, The maximum weight of 500 kernel Wt. , Biological Yield and Yield were to $T_{3}$,while the minimum records were to $T_{1}$ in both locations, but there was non significant differences in $\mathrm{HI}$ at the two locations, may relate to instability of HI due to different environments, positive effect of biofertilizer may resulted from its ability to increase the availability of Phosphorus and other nutrients especially under the specialty of the calcareous nature of the soil of the region which cause decreasing on the nutrients availability, results agree with (Kucey et al ., 1989, Tiwari et al ., 1989,Afzal et al ., 2005, and Ozuturk et al ., 2003).

Table (2): Studied Reproductive traits in Location 1 and Location 2.

\begin{tabular}{|c|c|c|c|c|c|c|c|c|}
\hline & \multicolumn{3}{|c|}{ Location 1. bakrajo } & \multicolumn{3}{c|}{ Location 2. Kanipanka } \\
\cline { 2 - 10 } Treatment & $\begin{array}{c}\text { Wt. of } \\
\begin{array}{c}500 \\
\text { kernel } \\
\mathrm{g}\end{array}\end{array}$ & $\begin{array}{c}\text { Biological } \\
\text { Yield Mg } \\
\text { ha-1 }\end{array}$ & $\begin{array}{c}\text { Yield } \\
\mathrm{Mg} \\
\text { ha-1 }\end{array}$ & HI & $\begin{array}{c}\text { Wt. of } \\
500 \\
\text { kernel } \\
\mathrm{g}\end{array}$ & $\begin{array}{c}\text { Biological } \\
\text { Yield Mg } \\
\text { ha-1 }\end{array}$ & $\begin{array}{c}\text { Yield } \\
\mathrm{Mg} \\
\text { ha-1 }\end{array}$ & HI \\
\hline T1 & 91.096 & 14.916 & 5.586 & 0.374 & 94.02 & 16.694 & 6.113 & 0.366 \\
\hline T2 & 92.151 & 15.556 & 6.029 & 0.366 & 94.633 & 16.595 & 6.177 & 0.37 \\
\hline T3 & 93.165 & 16.046 & 6.516 & 0.385 & 95.722 & 17.833 & 6.958 & 0.39 \\
\hline L.S.D & 1.308 & 0.699 & 0.504 & NS & 1.021 & 0.714 & 0.506 & NS \\
\hline
\end{tabular}


The biofertilizer effect on the root-shoot ratio at the different stages of the growth was shown in tables 3 and 4 and the figures 1 and 2, indicating an increase in the root growth much more due to using phosphorus biofertilizer $\left(\mathrm{T}_{2}\right)$ than the situation of using chemical fertilizer only $\left(\mathrm{T}_{1}\right)$, Shoot dry matter production was reduced to a higher degree than root length, resulting in a higher root-shoot ratio (RS) due to biofertilizer effect. There was larger root-shoot ratio at the period presilking due $T_{3}$ treatment in compare to $T_{1}$ and $T_{2}$ especially at Bakrajo with higher growth rate, and maximum weight of root growth recorded at the silking stage which was considered as the end of vegetative growth, showing larger root-shoot ratio at the silking stage. There were similar performance with few differences in Kanipanka, the results agree with similar research (Ozturk et al ., 2003, Salomone and Dobereiner, 2003).

Table (3): Root-Shoot ratio measured at pre-silking, At silking and post-silking(Loc.1)

\begin{tabular}{|c|c|c|c|c|l|l|l|l|c|}
\hline \multirow{3}{*}{ Treatments } & \multicolumn{3}{|c|}{ presilking } & \multicolumn{3}{c|}{ At Silking } & \multicolumn{3}{c|}{ Post Silking } \\
\cline { 2 - 11 } & $\begin{array}{c}\text { Root } \\
\text { DW }\end{array}$ & $\begin{array}{l}\text { Shoot } \\
\text { DW }\end{array}$ & R/S & $\begin{array}{l}\text { Root } \\
\text { DW }\end{array}$ & $\begin{array}{l}\text { Shoot } \\
\text { DW }\end{array}$ & R/S & $\begin{array}{l}\text { Root } \\
\text { DW }\end{array}$ & $\begin{array}{l}\text { Shoot } \\
\text { DW }\end{array}$ & R/S \\
\hline T1 & 1.68 & 10.176 & 0.165 & 32.583 & 213.888 & 0.152 & 36.333 & 178.583 & 0.204 \\
\hline T2 & 1.84 & 7.43 & 0.248 & 50.083 & 182.083 & 0.275 & 49.833 & 201.666 & 0.247 \\
\hline T3 & 2.75 & 10.19 & 0.27 & 36.555 & 188.861 & 0.194 & 39.583 & 190.861 & 0.207 \\
\hline LSD & NS & NS & & 3.699 & 13.957 & & 2.491 & 10.331 & \\
\hline
\end{tabular}

Table(4): Root -Shoot ratio measured at pre-silking, At silking and post-silking(Loc.2)

\begin{tabular}{|c|c|c|l|l|l|l|l|l|l|}
\hline \multirow{3}{*}{ Treatments } & \multicolumn{3}{|c|}{ presilking } & \multicolumn{3}{c|}{ At Silking } & \multicolumn{3}{c|}{ Post Silking } \\
\cline { 2 - 11 } & $\begin{array}{c}\text { Root } \\
\text { DW }\end{array}$ & $\begin{array}{l}\text { Shoot } \\
\text { DW }\end{array}$ & R/S & $\begin{array}{l}\text { Root } \\
\text { DW }\end{array}$ & $\begin{array}{l}\text { Shoot } \\
\text { DW }\end{array}$ & R/S & $\begin{array}{l}\text { Root } \\
\text { DW }\end{array}$ & $\begin{array}{l}\text { Shoot } \\
\text { DW }\end{array}$ & R/S \\
\hline T1 & 2.354 & 12.666 & 0.186 & 38.455 & 286.2 & 0.134 & 42.555 & 198.666 & 0.214 \\
\hline T2 & 3.75 & 12.289 & 0.305 & 65.324 & 225.025 & 0.29 & 66.75 & 246.583 & 0.271 \\
\hline T3 & 3.983 & 13.8 & 0.289 & 48.975 & 228.987 & 0.214 & 57 & 225.916 & 0.252 \\
\hline L.S.D & NS & NS & & 9.585 & 35.656 & & 3.826 & 15.163 & \\
\hline
\end{tabular}

Root Dry Weight increase may came from the elongation of the roots under the effect of the phosphorus biofertilizer which induced the uptake ability of the roots to nutrients and positive increase in the yield parameters because of improving the root system as a source-sink relationship to the reproductive part (shoot), that agree with (Mohammed et al ., 2001 ), (Ozturk et al ., 2003) and (Panwar et al ., 2006). There were an indications to shoot increase too under the effect of biofertilizer because there were general modification in growth performance. 


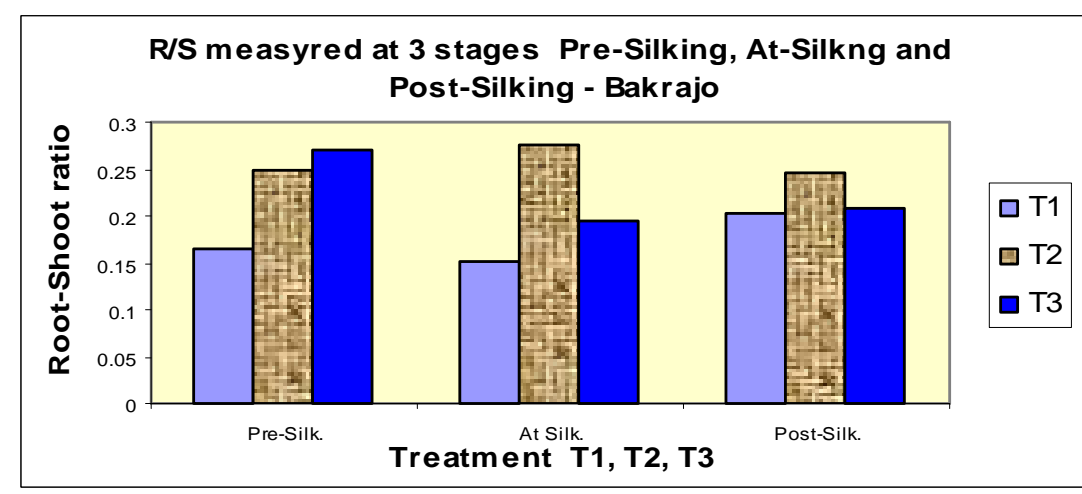

Fig.1: Root-Shoot ratio of three stages pre-silking, atsilking and post silking in Bakrajo.

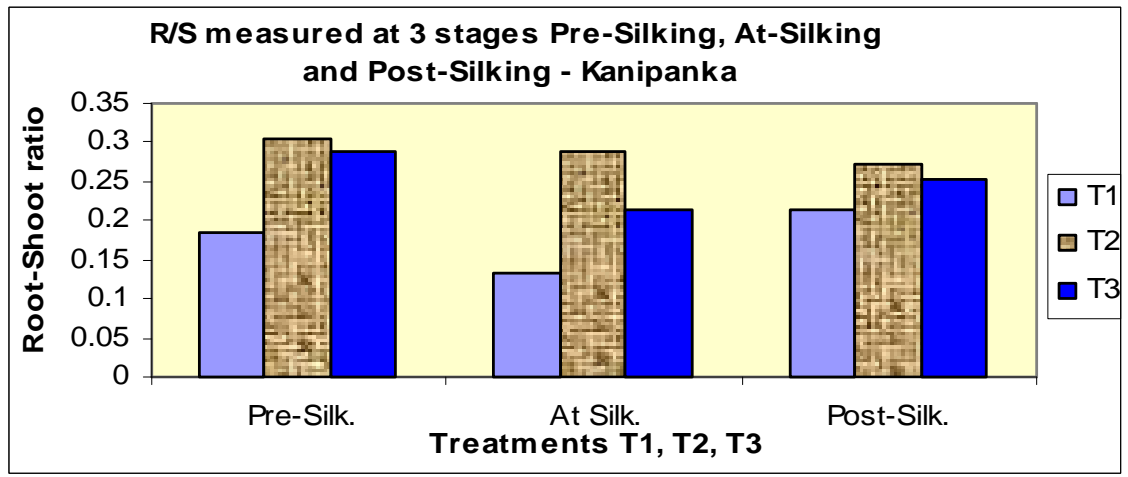

Fig.2: Root-Shoot ratio of three stages pre-silking, at-silking and post silking in Kanipanka

Table 5 and 6 show significant differences between the two locations due to physiology of growth which represented by dry matter accumulation and its patitioning to the root and shoot parts. It was noticed that growth rate at location 2 was more larger than location 1 due to most of the studied traits(although there were non significant differences between the two locations due to kernel yield and harvest index), there were significant increasing in the dry weight of shoot and root in the kanipanka location than in Bakrajo except the prestilking stage which was non significant, that may related to the favorite of some environmental factors in kanipanka which directly affected the bio fertilizer and its impact on the nutrient availability and growth (table 1,2), which positively influenced the maize photosynthesis and dry matter accumulation more actively that agree with (Lin et al ., 1983, Salmone and Dobereiner, 2004, Shevananda, 2008, and Darzi et al ., 2009).

Table (5 ):Root-Shoot weight at different stages of growth in $\mathrm{L}_{1}$ and $\mathrm{L}_{2}$ 


\begin{tabular}{|c|c|c|c|c|c|c|}
\hline Location & $\begin{array}{l}\text { Root } \\
\text { Wt. } \\
\text { Presilk } \\
\text { ing }\end{array}$ & $\begin{array}{l}\text { Shoot Wt. } \\
\text { Presilking }\end{array}$ & $\begin{array}{c}\text { Root } \\
\text { Wt. At } \\
\text { Silking }\end{array}$ & $\begin{array}{c}\text { Shoot Wt. } \\
\text { At Silking }\end{array}$ & $\begin{array}{c}\text { Root Wt. } \\
\text { Post } \\
\text { Silking }\end{array}$ & $\begin{array}{c}\text { Shoot Wt. } \\
\text { Post } \\
\text { Silking }\end{array}$ \\
\hline Bakrajo & 2.09 & 9.265 & 3.699 & 13.957 & 41.916 & 190.37 \\
\hline Kanipanka & 3.356 & 12.918 & 9.585 & 35.656 & 55.435 & 223.722 \\
\hline L.S.D & NS & NS & 5.859 & 21.318 & 2.636 & 10.593 \\
\hline
\end{tabular}

Growth improvement and yield and biomass increasing was reported with the biofertilizer application which account important benifet to the maize producers and maize production in the region, causing decreasing in the inputs of production because of economizing much money to chemical fertilizers and increasing in yield and biological yield in the production of the unit area, as well as its undamaged effect on the soil and environment, and on other hand its positive effect on physiology of growth performance.

Table( 6) : Studied traits of growth and yield in $\mathrm{L}_{1}$ and $\mathrm{L}_{2}$

\begin{tabular}{|c|c|c|c|c|c|c|c|c|}
\hline Location & $\begin{array}{c}\text { Days to } \\
50 \% \\
\text { tasseling }\end{array}$ & $\begin{array}{c}\text { Plant } \\
\text { Height } \\
\mathrm{cm}\end{array}$ & LAI & $\begin{array}{c}\text { Filling } \\
\text { Period }\end{array}$ & $\begin{array}{c}\text { Wt. of } \\
\text { kernel } \\
\mathrm{g}\end{array}$ & $\begin{array}{c}\text { Biological } \\
\text { Yield } \\
\mathrm{Mg}\end{array}$ & $\begin{array}{c}\text { Yield } \\
\mathrm{Mg}\end{array}$ & HI \\
\hline Bakrajo & 64.666 & 111.333 & 5.763 & 60.333 & 92.137 & 15.506 & 6.043 & 0.38 \\
\hline Kanipanka & 53.222 & 135.055 & 6.313 & 53.955 & 94.791 & 17.041 & 6.416 & 0.37 \\
\hline L.S.D & 0.872 & 2.835 & 0.503 & 1.539 & 0.958 & 0.575 & NS & NS \\
\hline
\end{tabular}

\section{تاثير التسميد الحيوي في فسلجة النمو و التطور للارة الصفراع في منطقة السليمانية

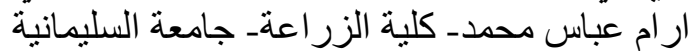 \\ الخلاصـة الزرة}

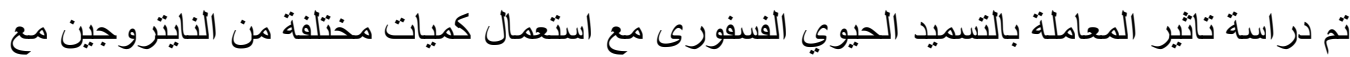

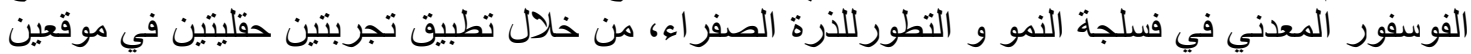

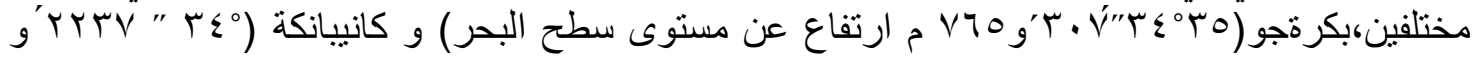

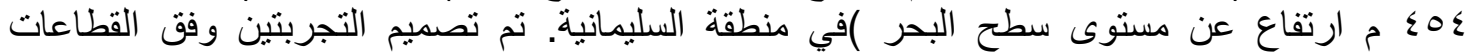

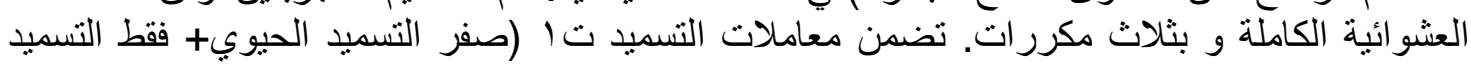

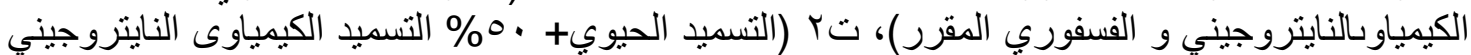

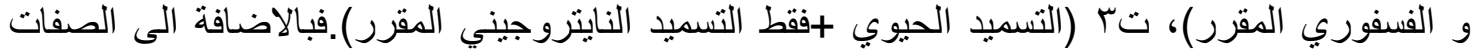

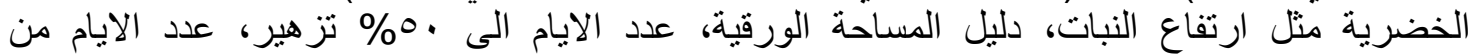

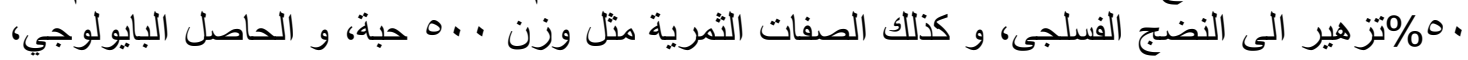

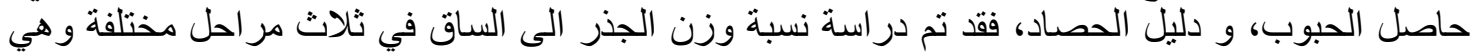
قبل ظهور الحريرة و اثناء ظهور الحريرة، و بعد ظهور الحريرة. اظهرت النتائج الازدياد في نسبة وزن 
الجذور الى الساق واختلافات معنويةبين الصفات المدروسة، مظهر ا استجابة موجبة لهجين الذرة الصفراء للتسميد الفوسفوري الحيوي.

\section{REFERENCES}

Afzal, A., M.Ashraf, S.A. Asad and M. Farooq. (2005). Effect of phosphate solubilizing microorganisms on phosphorus uptake, yield and yield traits of wheat (Triticum aestivum L.) in rainfed area. Int. J. Agric. Biol., 7: 207-9

Al-Sahoky, M. M. (1990). The Corn-Production and Breeding. Univ. of Mousl .( In Arabic)

Chabot, R., H. Antoun and M.P. Cescas.(1993). Stimulation de la croissance du maïs et de la laitue romaine par des microorganismes dissolvant le phosphore inorganique. Canadian J. Microbiol., 39: 941-7

Darzi, M.T., A. Ghavaland, and F.Rajali. (2009). The effects of biofertilizers application on N, P, K assimilation and seed yield infennel (Foeniculum vulgare Mill. Iranian Jor. For medicinal and aromatic plants. (25),(1).

El-Kholy, M.A.. S. El-Ashry, and A.M. Gomaa.(2005). Biofertilization of Maize Crop and its Impact on Yield and Grains Nutrient Content under Low rats of Mineral Fertilizers. Journal of Applied Sciences Research 1(2): 117-121.

Fulchieri. M. and L. Frioni.(1994). Azospirillum inculation on maize(Zea mays): Effect of yild in a field experiment in central Argentina.Soil.Biol.Biochem., 26: 921-924.

Kucey, R.M.N., H.H. Janzen and M.E. Leggett. (1989). Microbially mediated increases in plant-available phosphorus. Ad. Agron., 42: 199-228

Lin, W., Y. Okon, and R. W. F. Hardy. (1983). Enhanced mineral uptake by Zea mays and Sorghum bicolor roots inoculated with Azospirillum brasilense. Appl. Environ. Microbiol. 45:1775-1779.

Mohammed, A.S., M.A. AbdelMonem, H. E. Khalifa, M. Beider, I.A. El Ghandour, Y.G.M.Galal. (2001). Using biofertilizers for maize production:response and economic return under different irrigation treatments. Jor.of Sustainable Agricultur, (19). 41-48.

Okon, Y.(1985). Azospirillum as a potential inoculant for agriculture . Trends in Biotechnology. (3). 223-228.

Öztürk, A., O. Ca glar and F. Sahin. (2003). Yield response of wheat and barley to inoculation of plant growth promoting rhizobacteria at various levels of nitrogen fertilization. J. Plant Nutr. Soil Sci., 166:1-5

Panwar, A.S., N.P.Singh, D.C.Saxena, U.K. Hazarika. (2006). Yield and quality of groundnut seed as influence by phosphorus, biofertilizer and organic manures. Indian Journal of Hill Farming, (CAB abstracts).

Salomone, G., and J. Dobereiner.(2004). Maize genotype effects on the response to Azospirillum inculation. Biology and Fertility of soils, 21. ( 3) 193-196.

Sarig, S., Y. Okon, and A. Blum,(1990). Promotion of leaf area development and yield in Sorghum bicolor inoculated with Azospirillum brasilense. Symbiosis, 9: 235-245. 
Shaharoona, B., M. Arshad and Z.A.Zahir. (2006). Effect of plant growth promoting rhizobacteria containing ACC-deaminase on maize(Zea mays L.) growth under axenic conditions and on nodulation in mung bean( Vigna radiate L.)Institute of soil and environmental Science, Univ. of Agriculture, Faisalabad, Pakistan.

Shekh, B.A.(2006). Biotechnology and biofertilization: Key to sustainable agriculture. Scientific issue, (1) Das, K., R.Dang, T. N.

Shevananda. (2008). Influence of bio-fertilizers on the availability of nutrients (N, $\mathrm{P}$ and $\mathrm{K}$ ) in soil in relation to growth and yield of

Stevia rebaudiana grown in South India. International Journal of Applied Research in Natural Products, Vol. 1(1), pp. 20-24.

Tiwari, V.N., L.K. Lehri and A.N. Pathak. (1989). Effect of inoculating crops with phospho-microbes. Exp. Agric., 25: 47-50 
Appendix 1.Mean square of studied vegetative and reproductive traits for two locations

\begin{tabular}{|c|c|c|c|c|c|c|c|c|c|}
\hline \multirow[b]{2}{*}{ S.O.V } & \multirow[b]{2}{*}{ d.f } & \multicolumn{8}{|c|}{ M.S } \\
\hline & & $\begin{array}{c}\text { Days to } \\
50 \% \\
\text { tasselin } \\
\mathrm{g}\end{array}$ & $\begin{array}{l}\text { Plant } \\
\text { Height } \\
\mathrm{cm}\end{array}$ & LAI & $\begin{array}{l}\text { Filling } \\
\text { Period }\end{array}$ & $\begin{array}{l}\text { Wt. of } \\
500 \\
\text { kernel } \\
\text { g }\end{array}$ & $\begin{array}{r}\text { Biological Yield } \\
\mathrm{Mg}\end{array}$ & $\begin{array}{l}\text { Yield } \\
\mathrm{Mg}\end{array}$ & $\mathrm{HI}$ \\
\hline Location & 1 & 589.388 & $\begin{array}{c}2532.3 \\
47 \\
\end{array}$ & 1.362 & 183.042 & 31.702 & 10.599 & 1.592 & 1.3938 \\
\hline Blocks/Loc. & 4 & 0.444 & 4.694 & 0.148 & 1.384 & 0.536 & 0.194 & 0.299 & 0.0008 \\
\hline Biofertilizer/Loc. & 4 & 2.222 & 25.888 & 1.105 & 13.934 & 2.719 & 1.192 & 0.483 & 0.0003 \\
\hline Biofertilizer & 2 & 3.722 & 51.722 & 1.973 & 20.934 & 5.355 & 2.106 & 0.929 & 0.0006 \\
\hline $\begin{array}{c}\text { Biofertilizer*Loc } \\
\text { ation }\end{array}$ & 2 & 0.722 & 0.055 & 0.236 & 6.933 & 0.084 & 0.276 & 0.037 & 7.07 \\
\hline Error & 4 & 0.222 & 2.347 & 0.074 & 0.692 & 0.268 & 0.097 & 0.149 & 0.0004 \\
\hline
\end{tabular}


Appendix 2 Mean square of Root and Shoot dry weight for two location

\begin{tabular}{|c|c|c|c|c|c|c|c|}
\hline S.O.V & $\mathrm{df}$ & $\begin{array}{l}\text { Root Wt. } \\
\text { pre-Silking }\end{array}$ & $\begin{array}{l}\text { Shoot Wt. } \\
\text { Pre-Silking }\end{array}$ & $\begin{array}{l}\text { Root Wt. } \\
\text { At-Silking }\end{array}$ & $\begin{array}{l}\text { Shoot } \\
\text { Wt.At- } \\
\text { Silking }\end{array}$ & $\begin{array}{c}\text { Root } \\
\text { Wt.Post - } \\
\text { Silking }\end{array}$ & $\begin{array}{c}\text { Shoot } \\
\text { Wt.Post- } \\
\text { Silking }\end{array}$ \\
\hline Location & 1 & 7.216 & 60.046 & 562.208 & 12071.32 & 822.368 & 5005.568 \\
\hline Blocks/Loc. & 4 & 0.989 & 8.749 & 20.049 & 265.396 & 4.058 & 65.532 \\
\hline Biofertilizer/Loc. & 4 & 1.647 & 4.717 & 401.233 & 2178.826 & 296.741 & 1066.506 \\
\hline Biofertilizer & 2 & 2.718 & 7.327 & 767.812 & 3881.053 & 533.497 & 1898.486 \\
\hline $\begin{array}{l}\text { Biofertilizer } \mathrm{x} \\
\text { Location }\end{array}$ & 2 & 0.573 & 2.108 & 134.653 & 476.600 & 59.986 & 234.526 \\
\hline
\end{tabular}

Appendix 3: Meterological data of Bakrajo and Kanipanka of the duration from Jully to November 2009. 


\begin{tabular}{|c|c|c|c|c|c|c|c|c|c|}
\hline 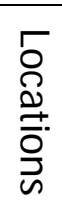 & Mon. & $\begin{array}{l}\text { Air } \\
\text { Temp } \\
{ }^{\circ} \mathrm{C}\end{array}$ & RH\% & $\begin{array}{l}\text { Precipitation } \\
\mathrm{mm}\end{array}$ & $\begin{array}{c}\text { Sun } \\
\text { shine } \\
\text { duration } \\
\text { (hr) }\end{array}$ & $\begin{array}{l}\text { Wind } \\
\text { speed } \\
(\mathrm{m} / \mathrm{s})\end{array}$ & $\begin{array}{c}\text { Soil } \\
\text { temp. }{ }^{\circ} \mathrm{C}\end{array}$ & $\begin{array}{c}\text { Pan } \\
\operatorname{evap}(\mathrm{mm})\end{array}$ & Cloud cover (oktas) \\
\hline \multirow{5}{*}{ 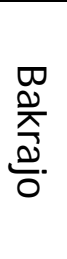 } & Jul & 32.4 & 24.2 & 0.0 & 9.5 & 1.3 & 30.3 & 9.6 & 0.1 \\
\hline & Aug & 31.6 & 25.1 & 0.0 & 10.3 & 10.3 & 31.0 & 8.6 & 0.0 \\
\hline & Sep & 26.2 & 34.3 & 0.3 & 9.0 & 9.0 & 27.1 & 5.4 & 1.1 \\
\hline & Oct & 22.5 & 38.6 & 2.4 & 7.6 & 7.6 & 20.4 & 4.2 & 2.1 \\
\hline & Nov & 13.2 & 68.3 & 4.5 & 5.2 & 5.2 & 12.6 & 2.4 & 3.5 \\
\hline \multirow{5}{*}{ 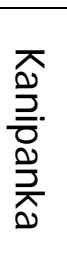 } & Jul & 33.2 & 23.3 & 0.0 & 8.7 & 2.40 & 35.8 & 12.6 & 2.3 \\
\hline & Aug & 34.2 & 22.2 & 0.0 & 10.7 & 2.30 & 35.7 & 12.3 & 0.4 \\
\hline & Sep & 28.5 & 28.4 & 2.9 & 9.2 & 2.10 & 31.5 & 8.9 & 1.7 \\
\hline & Oct & 23.7 & 30.3 & 26.7 & 7.8 & 1.80 & 25.4 & 5.7 & 2.3 \\
\hline & Nov & 13.1 & 58.8 & 14.6 & 5.5 & 1.50 & 15.2 & 1.8 & 3.4 \\
\hline
\end{tabular}

Appendex 4: Physical and Chemical analysis of the soil for the two locations

\begin{tabular}{|l|l|l|l|l|l|}
\hline Location & PSD & Texture name & Total N ppm & CaCO3\% & P-available $\mu g^{-1}$ \\
\hline
\end{tabular}




\begin{tabular}{|c|c|c|c|c|c|c|c|}
\hline & Clay & Silt & Sand & & & & \\
\hline Bakrajo & 501.7 & 449.8 & 48.5 & Silty Clay & 19.93 & 33.76 & 4.26 \\
\hline Kanipanka & 456.9 & 506.7 & 37.2 & Silty Clay & 27.66 & 34.26 & 5.7 \\
\hline \multirow{2}{*}{ Location } & \multicolumn{5}{|c|}{ Soluble cations and Anions Meq..$^{-1}$} & \multirow{2}{*}{$\mathrm{K}^{+} \mathrm{ppm}$} & \multirow{2}{*}{$\mathrm{Na}^{2+} \mathrm{ppm}$} \\
\hline & $\mathrm{Ca}^{2+}$ & $\mathrm{Mg}^{2+}$ & $\mathrm{CO}^{-}$ & $\mathrm{HCO}^{-}$ & $\mathrm{Cl}^{-}$ & & \\
\hline Bakrajo & 2.66 & 1.09 & 0 & 8.09 & 2.76 & 2.67 & 27.66 \\
\hline Kanipanka & 2.98 & 1.87 & 0 & 2.33 & 1.39 & 2.14 & 19.93 \\
\hline
\end{tabular}

